\title{
Ovarian mucinous borderline tumor accompanied by LGESS with myxoid change: a case report and literature review
}

\author{
Wen Wang ${ }^{1}$, Yalin Zhuang ${ }^{1}$, Feng Zhou ${ }^{2^{*}}$ and Lili Huang ${ }^{1}$
}

\begin{abstract}
Objectives: To report an extremely rare case of ovarian borderline mucinous cystic tumor accompanied by lowgrade endometrial stromal sarcoma (LGESS) with myxoid change.

Case presentation: A 42-year-old woman complained of lower left abdominal fullness. Her serum carcinoembryonic antigen, cancer antigen (CA) 125, and CA19-9 levels were normal. Magnetic resonance imaging showed a 10-cm cystic mass with a 5-cm nodule in its wall, and a laparoscopy indicated a cystic mass at the left adnexa. Histology indicated a cystic lesion consisting of proliferative gastrointestinal-type epithelium; the mural nodule had a characteristic of striking myxoid change, preservation of arteriolar pattern, and a "tongue-like" infiltration.
\end{abstract}

Conclusions: The diagnosis of ovarian mucinous borderline tumor accompanied by LGESS with myxoid change was appropriate.

Keywords: Mucinous borderline tumor, Mural nodules, LGESS, Myxoid change

\section{Background}

Mucinous cystic tumors of the ovary, whether benign, borderline, or malignant, may be associated with mural nodules of various types, including sarcomas, sarcomalike mural nodules, foci of anaplastic carcinoma, carcinosarcoma, mixed nodules, and leiomyomas $[1,2]$. The subject of this report is a mural nodule with features of a low-grade endometrial stromal sarcoma (LGESS) with myxoid change arising in an ovarian mucinous borderline tumor. To our knowledge, there are no reports of mucinous ovarian tumors accompanied by LGESS with myxoid change.

\section{Case report}

A 42-year-old woman complained of lower left abdominal fullness. Her serum carcinoembryonic antigen (CEA), cancer antigen (CA) 125, and CA19-9 levels

\footnotetext{
*Correspondence: fungchew@zju.edu.cn

${ }^{2}$ Department of Pathology, Women's Hospital, School of Medicine,

Zhejiang University, 1 Xueshi Road, Hangzhou 310006, Zhejiang, People's Republic of China

Full list of author information is available at the end of the article
}

were within normal limits. Magnetic resonance imaging (MRI) showed a 10-cm cystic mass at the pelvic cavity with a $5-\mathrm{cm}$ nodule in its wall. The laparoscopy showed a $10-\mathrm{cm}$ cystic mass at the left adnexa. The right ovary and uterus were grossly normal. The patient underwent left salpingo-oophorectomy and adhesiolysis. The patient was symptom free 10 months after surgery.

On macroscopic examination, the cyst measured $10 \mathrm{~cm}$ in maximal diameter and had a thickness of $0.2-0.5 \mathrm{~cm}$. This cystic tumor focally adhered to the peritoneum. The inner side was slightly uneven and attached with clot-like material in some area. The cyst had a solid mural nodule protruding from the wall into the lumen measuring up to $5 \times 4 \times 4 \mathrm{~cm}$ in size (Fig. 1a). The mass was found penetrating the surface of the cyst and invading to the tubal fimbria. The cut surface was fleshy and gray with the area of hemorrhage and necrosis (Fig. 1b).

Microscopic observation showed that the cystic walls were lined mainly by single-layered tall mucinous columnar epithelium (Fig. 2a). Some epithelium of cystic walls showed slightly atypical proliferation with glandular budding and stratification. The cells exhibited mild to 

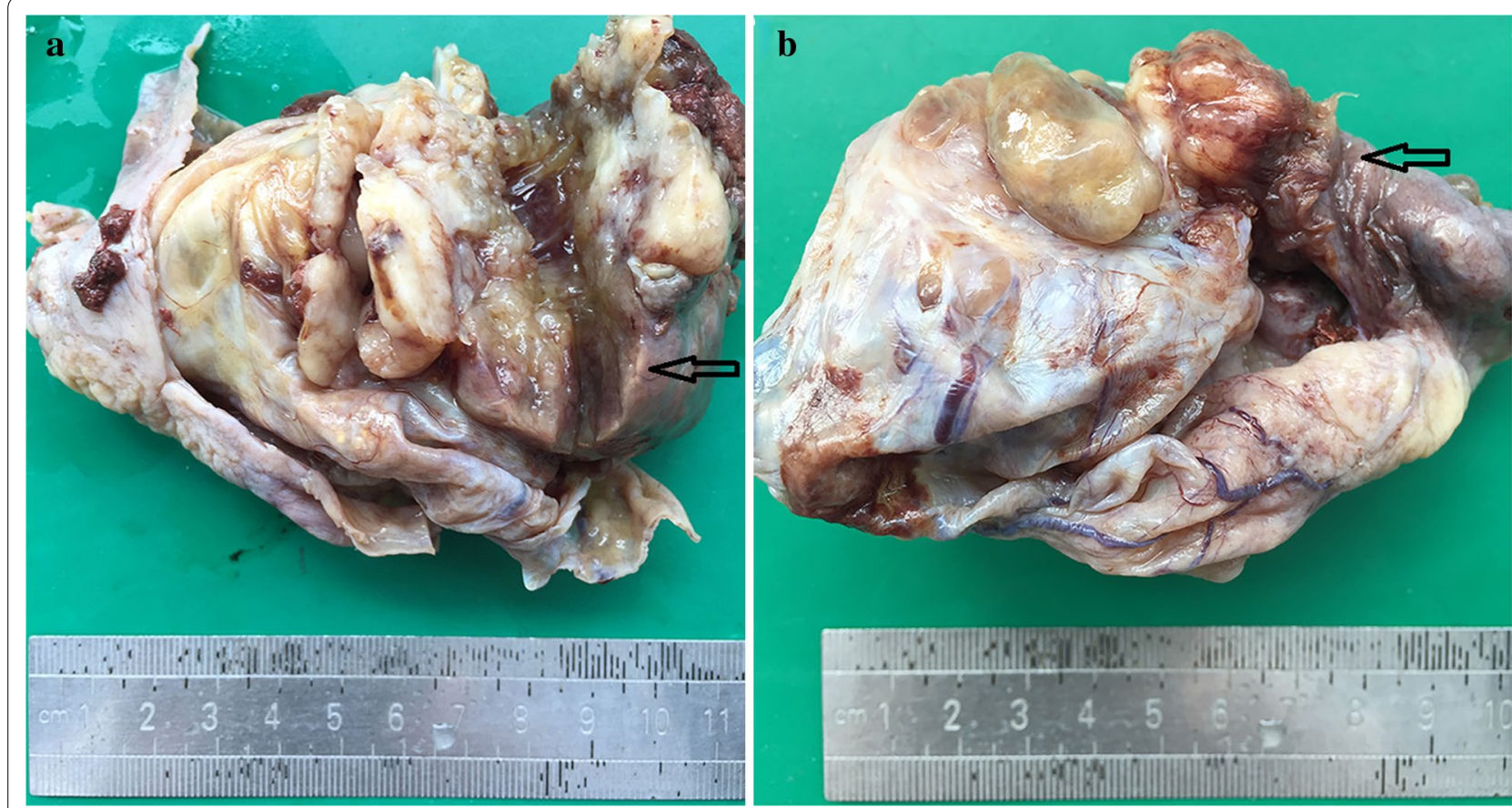

Fig. 1 Gross specimen of ovarian cystic mass with mural nodule: a solid mural nodule protruding into the cyst indicated with black arrows (a). Penetrating the surface of the cyst and invading to the tubal fimbria indicated with black arrows (b)

moderate nuclear enlargement and hyperchromasia. Acellular pools of mucin in the stroma were present in some areas (Fig. 2b). Old hemorrhage can be found in the cystic wall (Fig. 2c). In addition, there was a proliferation of large mononucleated cells and scattered multinucleated giant cells in an area of the cyst wall without forming a true nodule (Fig. $2 \mathrm{~d}$ ).

A 5- $\mathrm{cm}$ mural nodule was identified in the hysterectomy specimen protruding into the cystic cavity, extending onto the serosal, and involving the tubal fimbria. The mural nodule had a characteristic of striking myxoid change, preservation of arteriolar pattern, and a "tonguelike" infiltration (Fig. 3a). There was a sharp demarcation between epithelial and sarcomatous components (Fig. 3b). The mural nodule consisted of sheets of small cells with oval to spindle nuclei, whorling around spiral arteriole-like vessels (Fig. 3c). There was mild to moderate nuclear atypia and the mitosis was 4/10 HPF (Fig. 3d).

Immunohistochemical staining is shown in Fig. 4. The tumor cells of the mural nodule were strongly positive for cluster of differentiation 10 (CD10) and progesterone receptor (PR) and was negative for cytokeratin 7 (CK7), CK20, estrogen receptor (ER), a-inhibin, calretinin, caldesmon, and smooth muscle actin (SMA), which is a typical feature of endometrial stromal sarcoma. The tumor cells had a high index of Ki67. The epithelium of cystic wall was locally positive for CK7 and CK20.

Taking into account the above features, we made the diagnosis as ovarian mucinous borderline tumor accompanied by LGESS with myxoid change involving the tubal fimbria.

\section{Discussion}

In 1979, Prat and Scully [3] described in detail the clinicopathologic features of mural nodules emphasizing their broad morphologic spectrum and varying biological behavior. Since then, the scope of ovarian mural nodules has been classified into sarcoma-like, sarcoma, and anaplastic carcinoma [4]. The present case is quite interesting because of the presence of LGESS with myxoid change.

Mural nodules can develop in benign, borderline, or malignant ovarian tumors. These mural nodules are seen as solid lesions on the wall of the tumor or protrude into the cyst lumen. The diagnosis of mural nodules in the residual ovary is based on the size and characteristic gross and microscopic features $[5,6]$. The benign and reactive mural nodules, also called sarcoma-like mural 

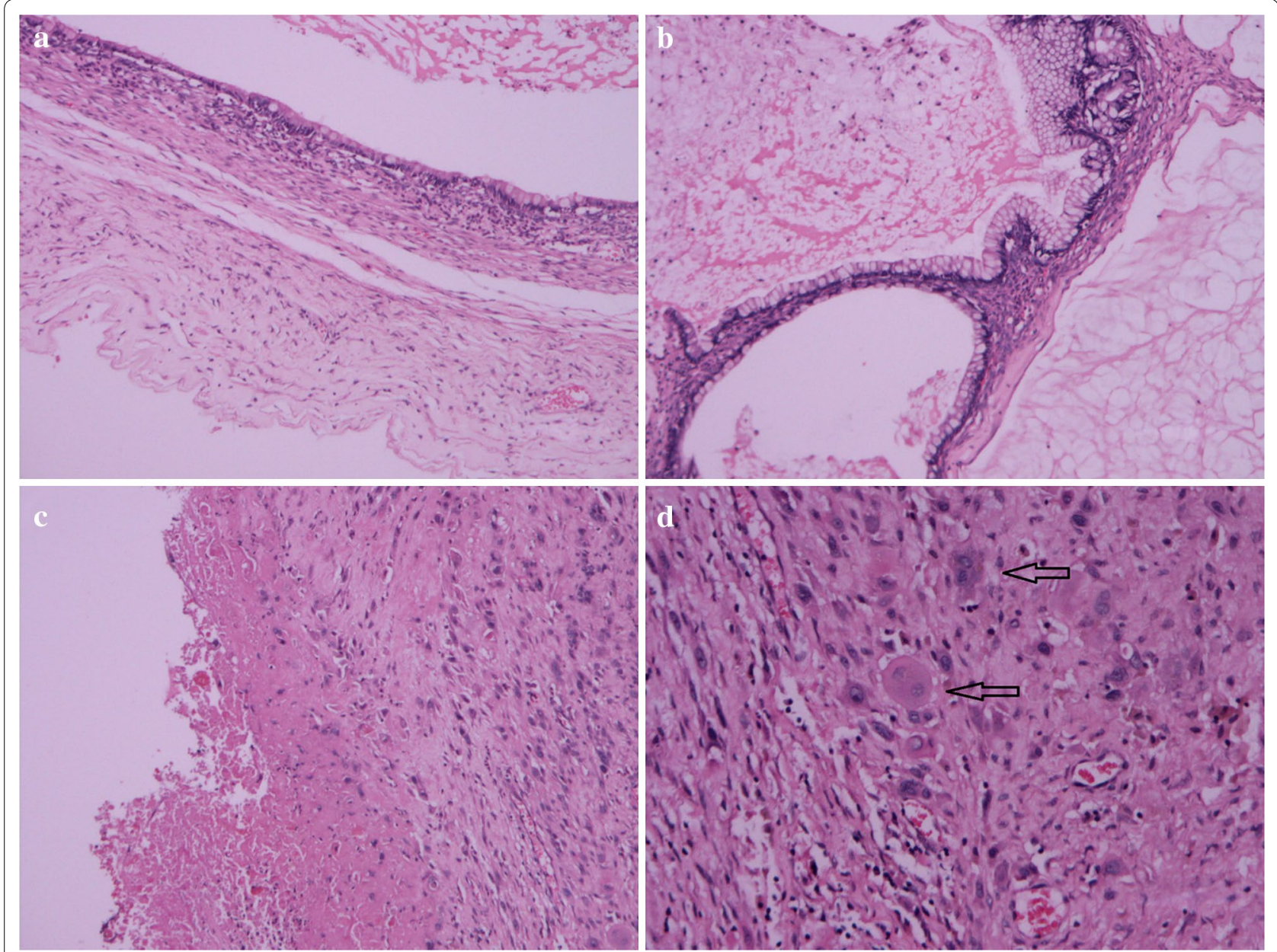

Fig. 2 Histological findings (H\&E). a Ovarian mucinous cystadenoma (x 10). b Borderline malignant mucinous cystadenoma and acellular pools of mucin $(\times 10)$. c Old hemorrhage in the cystic wall $(\times 10)$. $\mathbf{d}$ Proliferation of large mononucleated cells and scattered multinucleated giant cells indicated with black arrows $(\times 20)$

nodules (SLMNs), occur in younger females and are usually sharply demarcated small lesions. Malignant mural nodules are large solid tumors; as sarcoma and anaplastic carcinomas, they tend to occur in older females.

A review of the literature revealed only five mucinous ovarian tumors with sarcomas, with most of the mural nodules measured $>5 \mathrm{~cm}$ in the greatest dimension. In these five cases, they were fibrosarcomatous mural nodule in an ovarian mucinous cystadenoma [7], fibrosarcoma arising in a mucinous cystadenocarcinoma [8], fibrosarcoma associated with a mucinous cystadenoma [9], undifferentiated sarcoma in a mucinous cystadenocarcinoma [9], and rhabdomyosarcoma coexistent with ovarian mucinous cystadenocarcinoma [10], respectively. Ovarian mucinous borderline tumor accompanied by LGESS with myxoid change in our case was rather unique. The clinical and pathological features are summarized in Table 1.

The differential diagnosis for extrauterine LGESS depends on the location of the tumor. In case of ovarian location, ovarian sex cord-stromal tumors should be excluded. The pathological and morphological characteristics and immunohistochemical findings in the present case do not favor ovarian sex cord-stromal tumors. LGESS with myxoid change can be confused with myxoid smooth muscle lesions, but the "tonguelike" infiltration 


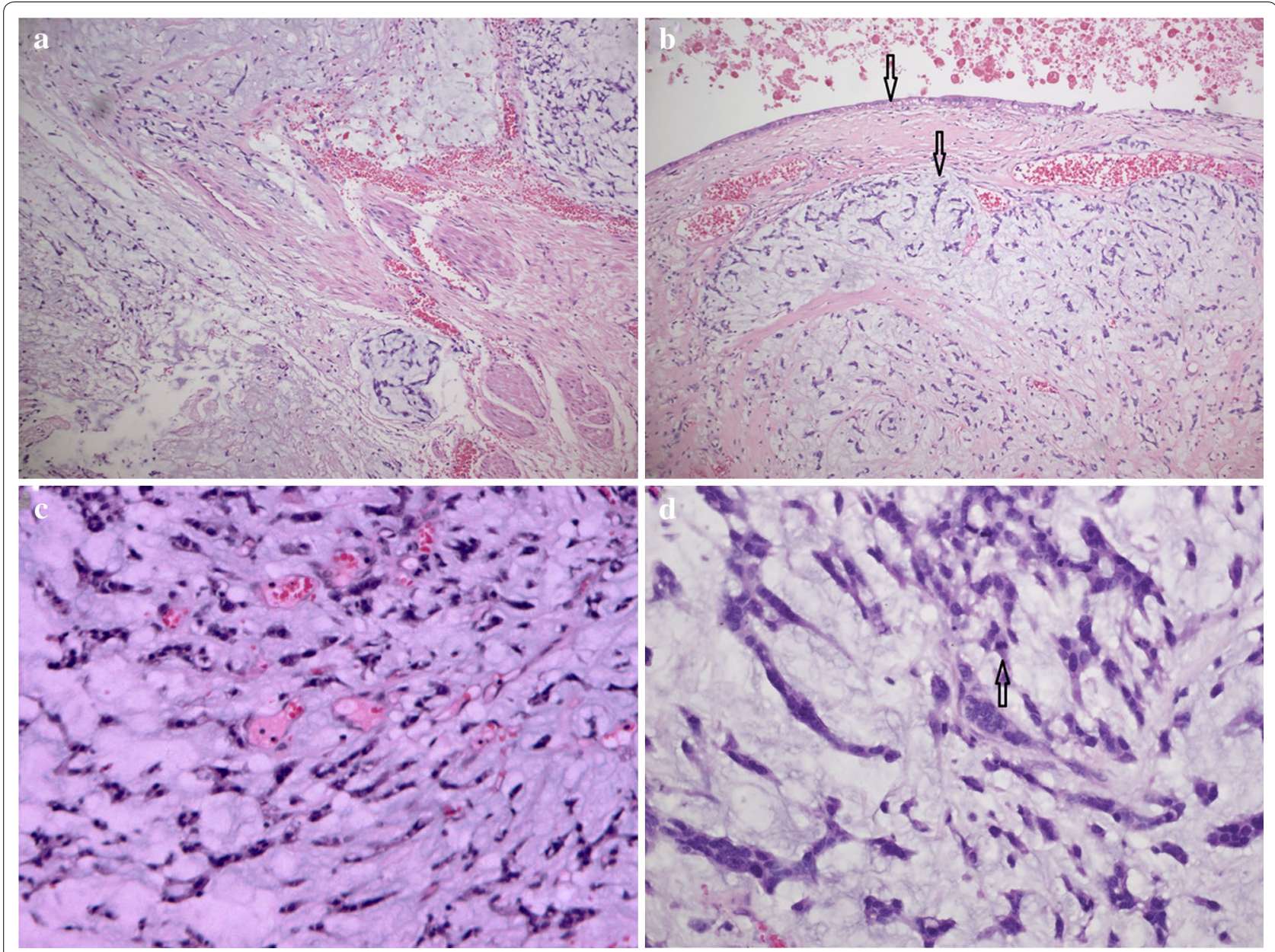

Fig. 3 Histological findings (H\&E). a Tongue-like processes extending into the edematous stroma $(\times 10)$. b Sharp demarcation between epithelial and sarcomatous components indicated with black arrows $(\times 10)$. c Preservation of arteriolar pattern $(\times 20)$. d Nuclear atypia and the mitosis indicated with black arrows $(\times 40)$

and small arterioles, along with the CD10 immunostaining and muscle marker negativity, will usually resolve the diagnosis.

Tumors with a combination of different histology are divided into two clinicopathologic groups, collision or composite tumors [11]. The collision tumor has more than two juxtaposed masses and each mass displays a different histology. In contrast, the intermingling of more than two different components in one tumor mass is designated as a composite tumor. The wellknown example is a malignant mixed Müllerian tumor (MMMT). It was noted that there was a sharp demarcation between epithelial and sarcomatous components in this case.
In this case, there was a region of proliferation of large mononucleated cells just beneath the epithelium without forming a true nodule, which may help explain the occurrence of malignant mural nodules. We hypothesize the forming process of this sarcoma as follows. The submesothelial mesenchymal cells reacted to the intramural hemorrhage or the mucinous content of the cyst, which eventually became a hyperplastic nodule, probably corresponding to the earlier stage of the SLMNs. Then the proliferation of mesenchymal cells resulted in the sustained expansion of the lesion. The nodule enlarged gradually and became SLMNs. Some of the SLMNs could possibly evolve into a true sarcoma with the proliferation and differentiation of mesenchymal cells. 

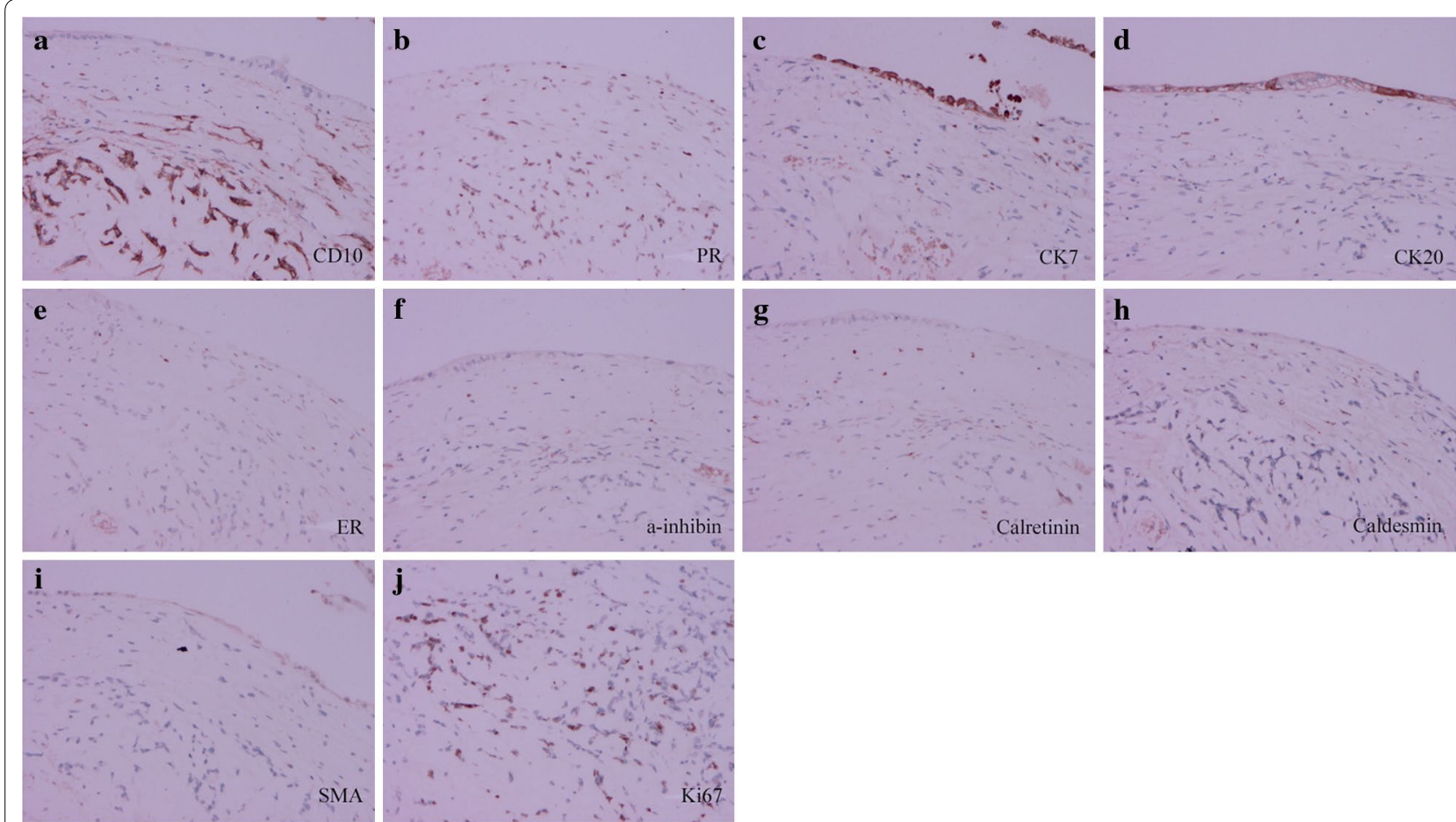

Fig. 4 Immunochemical photograph of the ovarian tumors: CD10 $(\mathbf{a}, \times 20)$, PR $(\mathbf{b}, \times 20), C K 7(\mathbf{c} \times 20)$, CK20 (d $\times 20)$, ER $(\mathbf{e}, \times 20)$, a-inhibin $(\mathbf{f}, \times 20)$ calretinin $(\mathbf{g}, \times 20)$, caldesmon $(\mathbf{h}, \times 20)$, SMA $(\mathbf{i}, \times 20)$, and Ki67 $(\mathbf{j}, \times 20)$

Table 1 Clinical and pathological features of mucinous ovarian tumors with sarcomas

\begin{tabular}{|c|c|c|c|c|c|c|c|c|c|}
\hline $\begin{array}{l}\text { Authors } \\
\text { [reference] }\end{array}$ & Age & Symptom & Figo stage & $\begin{array}{l}\text { No. of nod- } \\
\text { ules }\end{array}$ & Size $(\mathrm{cm})$ & Mural nodule & $\begin{array}{l}\text { Epithelial } \\
\text { ovarian } \\
\text { tumor }\end{array}$ & Treatment & Follow-up \\
\hline $\begin{array}{l}\text { De Nictolis } \\
\text { et al. [7] }\end{array}$ & na & na & na & na & na & Fibrosarcoma & $\begin{array}{c}\text { Mucinous cys- } \\
\text { tadenoma }\end{array}$ & na & na \\
\hline Rahilly et al. [8] & 69 & $\begin{array}{l}\text { Lower } \\
\text { abdominal } \\
\text { pain }\end{array}$ & $\| A$ & One & na & Fibrosarcoma & $\begin{array}{l}\text { Mucinous } \\
\text { cystadeno- } \\
\text { carcinoma }\end{array}$ & $\begin{array}{l}\text { TAH- } \\
\text { BSO + appen- } \\
\text { dicec- } \\
\text { tomy + CTX }\end{array}$ & $\begin{array}{c}\text { ned at } 12 \\
\text { month }\end{array}$ \\
\hline \multirow[t]{2}{*}{ Scully et al. [9] } & 61 & $\begin{array}{c}\text { Abdominal } \\
\text { swelling }\end{array}$ & $\mid A$ & One & 10 & Fibrosarcoma & $\begin{array}{c}\text { Mucinous cys- } \\
\text { tadenoma }\end{array}$ & $\mathrm{TAH}-\mathrm{BSO}+\mathrm{RT}$ & $\begin{array}{l}\text { Died at } 18 \\
\text { month }\end{array}$ \\
\hline & 49 & $\begin{array}{l}\text { Abdominal } \\
\text { swelling }\end{array}$ & IVB & One & 7 & $\begin{array}{l}\text { Undiffer- } \\
\text { entiated } \\
\text { sarcoma }\end{array}$ & $\begin{array}{l}\text { Mucinous } \\
\text { cystadeno- } \\
\text { carcinoma }\end{array}$ & $\begin{array}{l}\mathrm{BSO}+\mathrm{OT}+\text { peri- } \\
\text { aortic biopsy }\end{array}$ & Died at 1 week \\
\hline $\begin{array}{l}\text { Tsujimura et al. } \\
\text { [10] }\end{array}$ & 57 & $\begin{array}{l}\text { No obvious } \\
\text { symptoms }\end{array}$ & $\mid A$ & One & 15 & $\begin{array}{l}\text { Rhabdomyo- } \\
\text { sarcoma }\end{array}$ & $\begin{array}{l}\text { Mucinous } \\
\text { cystadeno- } \\
\text { carcinoma }\end{array}$ & TAH-BSO + CTX & ned at 3 month \\
\hline This work & 42 & $\begin{array}{l}\text { Abdominal } \\
\text { fullness }\end{array}$ & $\| A$ & One & 5 & $\begin{array}{l}\text { LGESS with } \\
\text { myxoid } \\
\text { change }\end{array}$ & $\begin{array}{l}\text { Mucinous } \\
\text { borderline } \\
\text { tumor }\end{array}$ & UA & $\begin{array}{c}\text { ned at } 10 \\
\text { month }\end{array}$ \\
\hline
\end{tabular}

ned, no evidence of disease; na, not available; TAH-BSO, tota abdominal hysterectomy and bilateral salpingo-oophorectomy; OT, omentectomy; SH, subtotal hysterectomy; UA, unilateral adnexectomy; RT, radiation therapy; CTX, chemotherapy 


\section{Conclusions}

We have presented a rare case of sarcoma-like mural nodule. Based on the ample evidence of the previous reports, and the immunohistochemical analysis of our case, we believe that this is a collision tumor with two different elements and may be formed by SLMN malignant change. Nevertheless, further molecular and genetic evidence is needed to support such a conclusion.

\section{Abbreviations}

LGESS: low-grade endometrial stromal sarcoma; CEA: carcinoembryonic antigen; CA125: cancer antigen 125; CA19-9: cancer antigen 19-9; MRI: magnetic resonance imaging; CD10: cluster of differentiation 10; PR: progesterone receptor; CK7: cytokeratin 7; CK20: cytokeratin 20; ER: estrogen receptor; SMA: smooth muscle actin; SLMN: sarcoma-like mural nodules; MMMT: malignant mixed Müllerian tumor.

\section{Authors' contributions}

All authors made substantial contributions to conception and design, or acquisition of data, or analysis and interpretation of data; WW and ZY were involved in drafting the manuscript and revising it critically for important intellectual content; ZF gave final approval to the version to be published. All authors read and approved the final manuscript.

\section{Author details}

${ }^{1}$ Department of Obstetrics and Gynecology, Women's Hospital, School of Medicine, Zhejiang University, Hangzhou, Zhejiang, China. ${ }^{2}$ Department of Pathology, Women's Hospital, School of Medicine, Zhejiang University, 1 Xueshi Road, Hangzhou 310006, Zhejiang, People's Republic of China.

\section{Acknowledgements}

$$
\text { Not applicable. }
$$

\section{Competing interests}

The authors declare that they have no competing interests.

\section{Availability of data and materials}

The datasets generated during and/or analyzed during the current study are available from the corresponding author on reasonable request.

\section{Consent for publication}

Written informed consent was obtained from the patient for publication of this case report and any accompanying images.

\section{Ethics approval and consent to participate}

This study was approved by the ethics committee of the Women's Hospital, School of Medicine Zhejiang University.

\section{Funding}

This work was supported by the program for Zhejiang Provincial Natural Science Foundation, P. R. China (No. LY12H04011).

\section{Publisher's Note}

Springer Nature remains neutral with regard to jurisdictional claims in published maps and institutional affiliations.

Received: 22 November 2016 Accepted: 22 November 2017

Published online: 02 December 2017

\section{References}

1. Park TC, Lee HN, Shin OR, Lee KH. A case of a borderline mucinous tumor of the ovary with sarcoma-like mural nodules producing granulocyte colony-stimulating factor. Eur J Gynaecol Oncol. 2012;33:526-7.

2. Bague S, Rodriguez IM, Prat J. Sarcoma-like mural nodules in mucinous cystic tumors of the ovary revisited: a clinicopathologic analysis of 10 additional cases. Am J Surg Pathol. 2002;26:1467-76.

3. Prat J, Scully RE. Ovarian mucinous tumors with sarcoma-like mural nodules: a report of seven cases. Cancer. 1979:44:1332-44.

4. Gungor T, Altinkaya SO, Akbay S, Bilge U, Mollamahmutoglu L. Malign mural nodules associated with serous ovarian tumor of borderline malignancy: a case report and literature review. Arch Gynecol Obstet. 2010;281:485-90.

5. Bague S, Rodriguez IM, Prat J. Sarcoma-like mural nodules in mucinous cystic tumors of the ovary revisited - a clinicopathologic analysis of 10 additional cases. Am J Surg Pathol. 2002;26(11):1467-76.

6. Chang JS, Chua CC, Lee CC. Borderline mucinous cystic ovarian tumor with mural nodules (carcinosarcoma). Ann Saudi Med. 2012;32(4):415-20.

7. De Nictolis M, Di Loreto C, Cinti S, Prat J. Fibrosarcomatous mural nodule in an ovarian mucinous cystadenoma: report of a case. Surg Pathol. 1990;3:309-15

8. Rahilly MA, Candlish W, Al-Nafussi A. Fibrosarcoma arising in an ovarian mucinous tumor: a case report. Int J Gynecol Cancer. 1994;4(3):211-4.

9. Prat J, Scully RE. Sarcomas in ovarian mucinous tumors: a report of two cases. Cancer. 1979;44:1327-31.

10. Tsujimura T, Kawano K. Rhabdomyosarcoma coexistent with ovarian mucinous cystadenocarcinoma: a case report. Int J Gynecol Pathol. 1992;11:58-62

11. Lewin K. Carcinoid tumors and the mixed (composite) glandular-endocrine cell carcinomas. Am J Surg Pathol. 1987;11:71-86.

\section{Submit your next manuscript to BioMed Central} and we will help you at every step:

- We accept pre-submission inquiries

- Our selector tool helps you to find the most relevant journal

- We provide round the clock customer support

- Convenient online submission

- Thorough peer review

- Inclusion in PubMed and all major indexing services

- Maximum visibility for your research

Submit your manuscript at www.biomedcentral.com/submit 